\title{
Uczony i czarodziej. Zmienne koleje losu mistrza Starewicza
}

\section{PAWEŁ SITKIEWICZ \\ Uniwersytet Gdański}

W tym roku przypada 50. rocznica śmierci Władysława Starewicza (1882-1965), ważnego pioniera sztuki filmowej. Jest on artystą, o którym warto pamiętać z kilku powodów. Po pierwsze, był jednym z prekursorów, a następnie mistrzów kina lalkowego. Jednak nawet w jego wczesnych produkcjach trudno doszukać się prostoty i naiwności charakterystycznej dla zjawisk filmowych, których poetyka dopiero się krystalizuje. Realizm świata przedstawionego, płynny ruch lalek i rozmach inscenizacji zachowały świeżość w dobie cyfrowych efektów specjalnych. Po drugie, Starewicz uchodzi za prekursora tendencji, które znalazły wybitnych kontynuatorów w osobach Jana Švankmajera, braci Quay, Tima Burtona czy Wesa Andersona. Uważa się, że to on wprowadził do animacji lalkowej ducha surrealizmu i makabreski. Po trzecie wreszcie, Starewicz całe życie czuł się Polakiem, mimo iż swe losy związał z Rosją, a następnie Francją. Nad Sekwaną rocznicę jego śmierci uświetniono edycją płyt DVD, okolicznościowymi projekcjami filmów, a także wystawą lalek. Byłoby źle, gdyby nad Wisłą wydarzenie to przeszło bez echa.

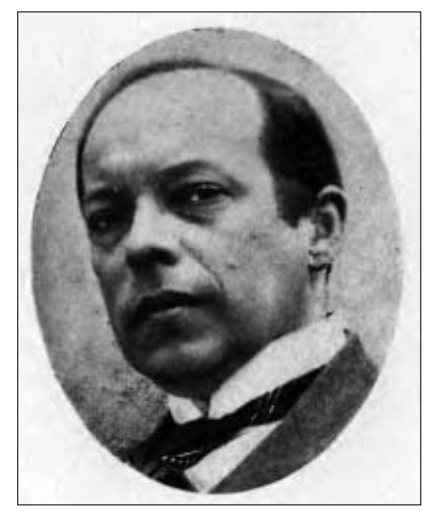

Władysław Starewicz (1882-1965)

[1] S. Kolbuszewski, Kraina baśni ożyła..., „Wielkopolska Ilustracja" 1929, nr 3, s. 21.
Okrągłe rocznice to dobry moment do pisania panegiryków. Ale w tym wypadku to niepotrzebny wysiłek. Wiele filmów Starewicza broni się bez pomocy adwokata. Dzięki Internetowi zdobył on nawet małą popularność jako „treser owadów” lub ekscentryczny animator, który ożywiał świat fauny i flory. Ale to mylny wizerunek. Przede wszystkim był postacią tragiczną oraz artystą osobnym i niespełnionym, na którego karierze wiek XX odcisnął głębokie piętno.

Władysław Starewicz nie osiągnął sukcesu komercyjnego, na który zasługiwał i na którym mu zależało. W wielu kręgach był zupełnie nieznany. Co prawda jego biografowie, Léona Béatrice Martin-Starewitch i François Martin oraz Władysław Jewsiewicki, zwracają uwagę na uznanie, jakim cieszył się przed rokiem 1939, gdy stawiano go $\mathrm{w}$ jednym rzędzie $\mathrm{z}$ samym Waltem Disneyem, a także cytują pochlebne recenzje, jednak z lektury przedwojennych czasopism wyłania się nieco inny obraz. To prawda, filmy Starewicza wielokrotnie chwalono za artyzm i doskonały warsztat. To prawda, komplementowano go za talent i upór, a do jego studia w podparyskim Fontenay-sous-Bois ustawiała się kolejka chętnych, by ujrzeć miniaturowy świat jak ze snu i uścisnąć rękę „czarodzieja ekranu”. Ale filmy - może z wyjątkiem Francji - na ogół kierowano do wąskiej dystrybucji, w wielu krajach pokazywano je w charakterze zwykłych dodatków do pełnometrażowego seansu lub nie pokazywano ich wcale. Nawet Polska, gdzie z dumą pisano, że filmy Starewicza, „przebiegając ekrany Europy i Ameryki, roznoszą sławę imienia artysty polskiego i sławę Polski”[1], nie była tutaj wyjątkiem. Gdy w roku 1931 sprowadzono do Poznania dwie kopie, Magicznego zegara i Zaczarowanego lasu, rozpowszechniano je 
bez należnego rozgłosu ze strony krytyki czy odpowiednich instytucji[2].

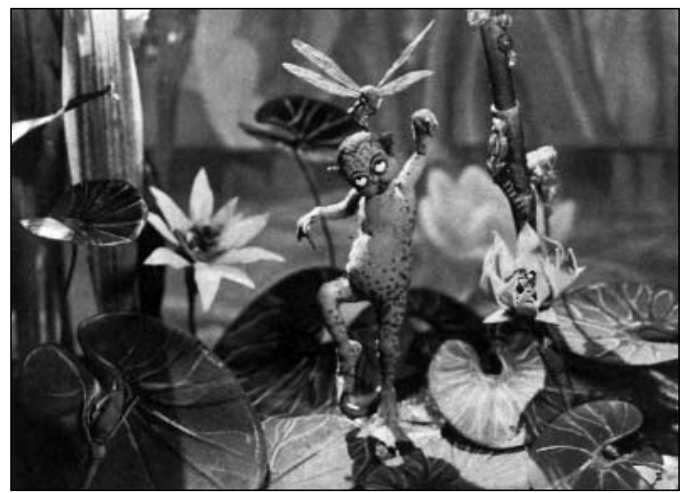

Zaczarowany las Władysława Starewicza. Jeden z nielicznych filmów tego twórcy dystrybuowany w Polsce

W roku 1936 pewien publicysta zauważył, że nazwisko Starewicza, „[...] usunięte obecnie w cień, może wielu nic nie mówić. Tymczasem przyszły badacz rozwoju kina będzie musiał poświęcić mu osobny i wcale pokaźny rozdział" [3]. Były to słowa prorocze.

\section{Zmagania $\mathrm{z}$ historia}

Wiele faktów z życia Władysława Starewicza dowodzi, że jego utraconą arkadią była przedrewolucyjna Rosja. Na lata 1909-1914 przypada najbardziej dynamiczny etap jego twórczości, który wyznaczają debiut, pierwsze sukcesy $\mathrm{w}$ roli animatora, współpraca z Aleksandrem Chanżonkowem i awans do roli reżysera filmów pełnometrażowych, łączących „żywą akcję”, animację i triki. Przed pierwszą wojną światową kino amerykańskie nie miało jeszcze monopolu na światowym rynku filmowym, a repertuar krótkometrażowy - zwłaszcza oparty na innowacyjnej technice i nowatorski pod względem wizualnym - mógł liczyć na szerokie rozpowszechnianie. Zdaniem Władysława Jewsiewickiego, animacje Starewicza były pierwszymi filmami z Rosji, które sprzedano za granicą[4]. Firma A. Chanżonkow \& Co. uchodziła wówczas za czołowego producenta w tej części świata, toteż kariera Starewicza rysowała się w jasnych bar- wach. Jego filmografia sprzed roku 1920 liczy przeszło 70 tytułów.

W przededniu pierwszej wojny światowej założył nawet własne studio. Był to, niestety, zły moment na taką decyzję, ale nikt nie mógł wówczas przewidzieć losów Europy... Gdy wybuchła rewolucja, Starewicz łudził się, że opuszcza Moskwę na chwilę i że zaraz wróci do rozpoczętych projektów filmowych. Ale po długiej i dramatycznej tułaczce, m.in. w bydlęcych wagonach i pieszej przez bezkresne śniegi, dotarł wraz z rodziną wpierw do Jałty, następnie do Włoch, a ostatecznie, pod koniec roku 1920, osiadł we Francji, jak wielu innych uciekinierów z bolszewickiej Rosji. Jak wspominała Irena Starewiczówna, jej ojciec był „człowiekiem czysto słowiańskiej kultury”, który we Francji czuł się początkowo wyobcowany (nie znał nawet języka) i dopiero po kilku latach zasymilował się i zaczął tworzyć filmy będące amalgamatem kilku kultur[5].

Te dramatyczne wydarzenia tworzą pęknięcie w jego artystycznym życiorysie. Stracił dom, studio i udał się na emigrację, gdzie musiał budować swój warsztat i pozycję niemal od zera. Rewolucyjne przeżycia tłumaczą chęć stworzenia azylu w małej willi pod Paryżem, lecz z drugiej strony - Starewicz nawet tam nie czuł się chyba komfortowo, skoro przez cały okres dwudziestolecia marzył o powrocie do Polski.

Już w roku 1927 zapowiadał, że chciałby przyjechać do ojczystego kraju w związku z planowaną ekranizacją Janka Muzykanta, by „pewne rzeczy poznać i zbadać na miejscu”[6].

[2] M. Geller, W świecie baśni i ułudy, „Nowy Kurier" 1931, 6 stycznia (nr 4), s. 5.

[3] Tad. C., Film makietowy, „Kino” 1936, nr 20, s. 10 .

[4] W. Jewsiewicki, Ezop XX wieku. Władysław Starewicz pionier filmu lalkowego i sztuki filmowej, WRiT, Warszawa 1986, s. 40.

[5] N. Nusinowa, Wotszebnik iz Fonteniu, „Kinowiedczeskije zapiski” [online] 2001, nr 52 [dostęp: 25 stycznia 2015], www.kinozapiski.ru/ru/article/ sendvalues/816/.

[6] J. Wyszomirski, Człowiek, który ożywia lalki, „Naokoło świata” 1927, nr 44, s. 76. 
Pod koniec lat 30. podpisał umowę $\mathrm{z}$ warszawską wytwórnią Kohorta. Miał stanąć na jej czele i zrealizować adaptację Pani Twardowskiej Mickiewicza. Zamierzał przyjechać latem 1939 roku i - co istotne - zostać w Polsce na stałe[7]. Wybuch wojny znów przekreślił marzenia o stabilizacji. Nie jest jasne, dlaczego Starewicz nie pojawił się w Warszawie w lipcu bądź sierpniu. Być może widmo wojny kazało mu wstrzymać się z przeprowadzką, a być może - to bardzo prawdopodobny scenariusz - Kohorta spóźniała się z oddaniem do użytku studia w Żyrardowie. Jak na ironię, gdy Starewicz szykował się do wyjazdu z Francji, Włodzimierz Kowańko, pionier filmu rysunkowego, myślał o opuszczeniu Polski, rozczarowany brakiem perspektyw.

Jeżeli nie uda mi się w kraju wyzyskać osiągniętych przeze mnie rezultatów dziesięcioletniej pracy, będę zmuszony wyemigrować za granicę, tym bardziej że tam proponują mi stworzenie odpowiedniego warsztatu do produkcji filmów rysowanych [...][8]

- mówił w wywiadzie z roku 1939. Powrót do Polski nie dawał gwarancji na odmianę losu. Tym bardziej że jego filmy były tu nieznane. Widzowie nie czekali na przyjazd Starewicza.

W dniu wybuchu wojny Starewicz po raz drugi znalazł się w tragicznym położeniu. Jego biografowie zgodnie potwierdzają, że chciał uniknąć współpracy z nazistowską kinema-

[7] (Kt), Mistrz baśni Władysław Starewicz wraca do Polski, „Ilustrowany Kurier Codzienny” 1939, nr 88.

[8] Włodzimierz Kowańko - twórca polskiego

filmu rysunkowego, „Aktualności Filmowe i Kinematograficzne" 1939, nr 5-6, s. 24.

[9] W. Jewsiewicki, op. cit., s. 184; L.B. Martin, F. Martin, Ladislas Starewitch 1882-1965,

L'Harmattan, Paris 2003, s. 183.

[10] Ch. Ford, R. Hammond, Polish Film:

A Twentieth Century History, McFarland \& Co.

Publishers, Jefferson-London 2005, s. 31.

[11] R. Giesen, R.P. Storm, Animation under the Swastika: A History of Trickfilm in Nazi Germany, 1933-1945, McFarland \& Co. Publishers, Jefferson 2012, s. 38.

[12] Ibidem, s. 40-41.

[13] L.B. Martin, F. Martin, op. cit., s. 178. tografią i okupantem, stawiając zbyt wysokie wymagania techniczne i finansowe[9]. Osiągnął połowiczny sukces. Na przełomie 1942 i 1943 roku przebywał w Berlinie, gdzie zrealizował dwa filmy reklamowe. Zdaniem Charlesa Forda, jako obywatel podbitego przez III Rzeszę państwa (w paszporcie miał wpisaną narodowość polską) dostał taki rozkaz. Gdy udało mu się wrócić do Fontenay, liczył się z aresztowaniem. Przygotował nawet plan ucieczki przez dach[10].

Jego sytuacja była o tyle trudna, że krótko przed wojną podjął owocną współpracę z UFA. Z prasy wynika, że wręcz o nią zabiegał[11]. W roku 1937 odbyła się premiera pełnometrażowego filmu Starewicza Reineke Fuchs, który został udźwiękowiony i oddany do dystrybucji dzięki wsparciu nazistowskiej kinematografii. Lalkowa adaptacja poematu Goethego była dla III Rzeszy projektem o małym znaczeniu propagandowym, ale ważnym dzięki nawiązaniu do niemieckiej tradycji romantycznej. Prasa pisała o filmie w samych superlatywach. Idąc za ciosem, Starewicz podobno planował w roku 1938 realizację swojego pierwszego filmu w kolorze pt. Abenteuer zweier deutsche Jungen. Pewien dziennikarz zapytał nawet, dlaczego on, Polak, zamierza kręcić film o niemieckich chłopcach. Starewicz odpowiedział, że „niemieccy chłopcy mają lepsze wyczucie natury”, a w witrynach niemieckich księgarni jest najwięcej na świecie książek na temat nauk przyrodniczych[12]. Ewidentnie próbował przypodobać się swojemu mecenasowi.

Również druga wersja Opowieści o Lisie (Le roman de Renard) weszła na ekrany w okolicznościach, które mogą świadczyć na niekorzyść Starewicza. Film miał bowiem premierę w roku 1941 w kolaborującej z III Rzeszą Francji Vichy. Biografowie reżysera zaznaczają jednak, że umowa $z$ producentem została podpisana jeszcze przed wojną i właśnie m.in. na skutek działań militarnych i okupacji opóźniła się data wejścia filmu do kin[13]. Po raz kolejny historia zostawiła rysę na artystycznym życiorysie Starewicza. Mimo wojennej zawieruchy Opowieść o Lisie osiągnęła co prawda znaczący sukces 
frekwencyjny, ale nie mogła liczyć na rozgłos adekwatny do rozmachu tego arcydzieła. Film wycofano $\mathrm{z}$ kin, aby zrobić miejsce dla antysemickiego Żyda Süssa (1940) Veita Harlana[14].

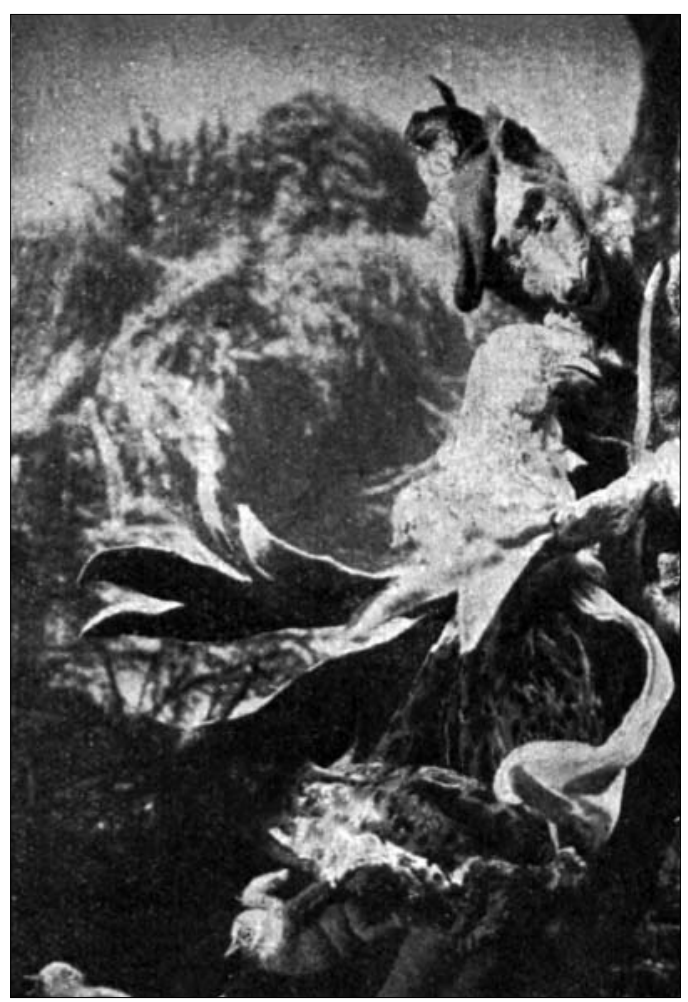

Opowieść o Lisie Władysława Starewicza. Ten pierwszy w historii kina pełnometrażowy film lalkowy czekał wiele lat na udźwiękowienie i dystrybucję

Zdaniem Williama Moritza, współpraca $\mathrm{z}$ nazistowską kinematografią to zawsze temat wstydliwy, dlatego często próbuje się ukryć bądź przemilczeć związek niektórych filmów animowanych $z$ hitlerowskim reżimem. Nie zmienia to faktu, że w III Rzeszy tworzyli najwybitniejsi animatorzy tamtej epoki, tacy jak Oscar Fischinger, Lotte Reiniger, bracia Diehl, Rudolf Pfenninger czy Władysław Starewicz[15]. Część z nich próbowała pozostać apolityczna, część miała zakaz opuszczenia kraju na stałe i tylko nieliczni udali się w końcu na emigrację. Współpracy Starewicza z UFA nie należy potępiać bez znajomości kontekstu historycznego, zwłaszcza że w jego filmach nie widać śladu ideologii czy politycznego zaangażowania. Prawdopodobnie chciał skorzystać z okazji, by oddać do dystrybucji film, który od kilku lat czekał gotowy na udźwiękowienie. Najciekawsze jest to, że w roku 1938 Starewicz musiał brać pod uwagę wszystkie wersje wydarzeń: pozostanie we Francji, powrót do Polski lub podpisanie nowej umowy z UFA.

\section{Blaski i cienie niezależności}

Przez całe lata 20. i 30. ubiegłego wieku Starewicz realizował filmy jako twórca niezależny. Prowadził domowe studio. Żona pomagała szyć kostiumy, młodsza córka Nina występowała na ekranie, a starsza Irena - realizowała filmy wspólnie z ojcem.

Warto podkreślić, że Starewicz po roku 1920 całkowicie poświęcił się animacji lalkowej, która przed wojną była nieznana szerszym kręgom widzów, przez co postrzegano ją bardziej krytycznie niż dziś. Twierdzono, że film lalkowy ma co prawda przyszłość i „rację bytu”, ale w porównaniu z kreskówką - dużo mniejszy potencjał artystyczny. Pisano, że „skala ruchliwości kukiełek jest nader szczupła w stosunku do rozbujałej fantazji filmu rysunkowego", wytykano „jednostajność dekoracji” i „brak możliwości abstrakcyjnych", a także skrępowanie prawami fizyki, które przestają działać dopiero na papierze[16]. Te zarzuty często znajdowały potwierdzenie w twórczości mniej uzdolnionych lub początkujących animatorów. Natomiast walka $\mathrm{z}$ negatywnym wizerunkiem wymagała czasu, pieniędzy, a zwłaszcza - popularyzacji wybitnych osiągnięć kina lalkowego.

Starewicz nigdy nie związał się na stałe $\mathrm{z}$ firmą, która wsparłaby go finansowo lub wzięła odpowiedzialność za dystrybucję filmów, żąda-

[14] Ibidem, s. 194.

[15] W. Moritz, Resistance and subversion in animated films of the Nazi era. The case of Hans Fischerkoesen, w: A Reader in Animation Studies, ed. by J. Pilling, John Libbey, Sydney 1997, s. 230. [16] A. Czermiński, Marionetki i film, „Czas” 1937, 19 grudnia (nr 347), s. 11. Krytyk przytacza zarzuty wobec filmu lalkowego, ale staje w obronie jego twórców, takich jak Starewicz. 
jąc w zamian uprzemysłowienia produkcji lub kręcenia cudzych scenariuszy. W prasie wypowiadał się na ogół buńczucznie, że nie boi się „ani Mickeya, ani teatru, ani konkurencji kina, z jego artystami, tak trudnymi do opanowania". $\mathrm{Z}$ drugiej strony, swoje położenie finansowe traktował jako smutną konieczność. „A że my sami nieczuli jesteśmy na złoto, którym chcą nas obsypać, więc zachowujemy niezależność..." [17] - mówił w wywiadzie. Przed wojną taka postawa wymagała determinacji i odwagi, albowiem nie był to przychylny czas dla niezależnych autorów $\mathrm{z}$ artystycznymi ambicjami. Jak wspominał Alexandre Alexeïeff, inny rosyjski animator pracujący we Francji, gdy zrealizował z Claire Parker 8-minutową Noc na Łysej Górze (Une nuit sur le Mont Chauve, 1934), prasa obwieściła sukces, ale żadna firma dystrybucyjna nie zainteresowała się wyświetlaniem filmu[18].

Nawet jeżeli znalazł się chętny przedsiębiorca, rzadko podpisywał kontrakt. Jak wyjaśnił Starewicz w wywiadzie z roku 1927: „Filmy moje są bardzo drogie. [...] Kupuje je właściwie tylko Ameryka. [...] Nawet we Francji trudno jest mi [je] sprzedać" [19]. Lalkowe produkcje Starewicza były bardzo czasochłonne w produkcji. Niektóre sceny, trwające na ekranie minutę, wymagały dwóch tygodni pracy, nie licząc wysiłku włożonego w konstrukcję marionetek i scenografii. Ich twórca miał mentalność średniowiecznego rzemieślnika, który długo cyzelował artystyczne rękodzieło, by sprzedać je od razu za dużą sumę, choć w tym samym cza-

[17] Z. Frenkiel, U twórcy filmów marionetkowych, „Światowid” 1936, nr 15, s. 29.

[18] Cyt. za: R. Russett, C. Starr, Experimental Animation. An Illustrated Anthology, Da Capo Press, New York 1975, s. 92.

[19] J. Wyszomirski, Człowiek, który ożywia lalki, „Naokoło świata” 1927, nr 44, s. 66.

[20] D. Crafton, Emile Cohl, Caricature, and Film, Princeton University Press, Princeton 1990, s. 208.

[21] An Equal Break, „Motion Picture News" 1925, no. 1, s. 1.

[22] Riesenfeld Gold Medal Award, „Film Year Book" 1926, s. 779. Zob. także W. Jewsiewicki, op. cit., s. 121. sie można było wyprodukować kilka tańszych wyrobów, powierzając pracę czeladnikom. Tego właśnie wymagał rynek. A konkurencja w tamtych czasach $\mathrm{z}$ roku na rok stawała się coraz ostrzejsza, a gusta widowni - mocno sprecyzowane. Jak pisał Donald Crafton w biografii kolejnego Francuza, Émile’a Cohla, od którego zresztą Starewicz podpatrzył technikę animacji:

Walka $\mathrm{z}$ amerykańską dominacją została przegrana w połowie lat 20. Publiczność we Francji - tak samo jak w każdym innym miejscu na świecie troszczyła się tylko o to, by zobaczyć więcej filmów z Kotem Feliksem, Klownem Koko i, po roku 1929, z Myszką Miki. Gdy francuscy intelektualiści zaczęli dostrzegać nowy gatunek, filmy Émile’a Cohla i jego następców [Crafton wymienia w tym gronie Starewicza - dop. P.S.] zostały zapomniane lub, w najlepszym wypadku, zapamiętane jako prehistoryczne skamieliny [20].

W latach 20. i 30. najbardziej opłacało się łączyć filmy animowane w serie. Starewicz co prawda uległ tej presji, tworząc w latach 1933-1937 cykl pięciu filmów o przygodach psa Fetysza, wyświetlany z sukcesem w kilku krajach, ale Walt Disney w tym samym czasie wprowadził na rynek aż 86 krótkometrażówek.

Postawa Starewicza spotykała się z brakiem zrozumienia, a nawet kąśliwymi uwagami krytyków. Dziennikarz „Motion Picture News” pisał ironicznie o filmie Słowiczy głos (La voix du rossignol, 1923), że szkoda siedemnastu miesięcy pracy na kilkaset metrów negatywu, niezależnie od efektu:

Wszystko świetnie! Ale ten człowiek, L. Starevitch, na pewno nie poświęci reszty swojego życia i całego intelektu na kolejne kreacje, jeżeli właściciel kina dalej będzie chciał kupować repertuar, kierując się długością filmów, a nie ich jakością. Warto więc poświęcić rok na realizację krótkiego metrażu, skoro w kilka tygodni można zrealizować materiał, który starczy na dłuższą fabułę?[21]

Takie były prawa rynku. Dla ścisłości dodam, że Słowiczy głos zdobył w roku 1925 nagrodę za najlepszy film krótkometrażowy wyświetlany w Ameryce. Starewicz, oprócz złotego medalu, otrzymał „kontrakt [...] na realizację serii tego rodzaju nowinek filmowych"[22], ale z propo- 
zycji nie skorzystał. Nie zgodził się na uprzemysłowienie produkcji, a pracując sam, potrafił nakręcić najwyżej 120 metrów (około 6 minut) negatywu miesięcznie.

\section{Teatr życia codziennego}

Wszyscy przedwojenni dziennikarze, którzy mieli przyjemność gościć w Fontenay-sous-Bois, jak mantrę powtarzali słowa o niedostępności mistrza Starewicza. „Czarodzieje nie lubią wpuszczać intruzów do swych sanktuariów. Inni w obawie, aby nie podpatrzono ich tajemnic, a ten w obawie przed utratą cennego czasu, którego mu ciągle brakuje" [23] - pisał jeden $\mathrm{z}$ nich. Z reportaży opowiadających o życiu i pracy polskiego animatora wyłania się dwuznaczny obraz: z jednej strony ekscentrycznego pustelnika, z drugiej zaś - człowieka gościnnego, ale stojącego na straży domowego azylu. Nie jest prawdą, że przez całe życie zazdrośnie strzegł tajemnic swojej sztuki, nie dopuszczając nikogo do swych sekretów. Tylko w pierwszych latach kariery, gdy większość widzów i krytyków nie miała świadomości, jak działa technika animacji, niechętnie dzielił się zdobytym doświadczeniem. Natomiast w latach 20. i 30. nie szczędził czasu dziennikarzom, opowiadając ze szczegółami o swoim warsztacie, a w roku 1932 nakręcił krótki reportaż o kulisach pracy w domowym atelier.

$\mathrm{Na}$ pewno był człowiekiem o nietuzinkowej osobowości, typem upartego Litwina przeświadczonego o słuszności swoich racji. $\mathrm{Z}$ trudem podejmował kompromisy. Nie miał w sobie nic z Walta Disneya, z którym tak chętnie go porównywano. Podejrzewam, że lubił aurę tajemnicy, która otaczała go od początku kariery, jakby zawód filmowca i przedsiębiorcy prowadzącego rodzinny interes szkodził jego wizerunkowi.

Jeszcze w latach poprzedzających rewolucję październikową przedstawiał się jako profesor Łoższkij (czyli Kłamca), który z pomocą naukowych metod nauczył swoje owady grać przed kamerą. Jak wykazał Jurij Cywjan, w swoich żartobliwych kreacjach Starewicz nawiązywał do modnych w tamtych latach dysput dotyczących genetyki i darwinizmu, mówiąc na przykład o długiej selekcji owadów, które w 453. generacji nauczyły się rozpoznawać swoje imiona i wykonywać komendy[24]. Laik mógł uznać, że brzmi to przekonująco. Były to więc kreacje starannie przygotowane, a nie tylko żarty z naiwnych widzów. Po pierwszej wojnie światowej Starewicz zrezygnował z naukowego entourage'u i chętniej pozował na czarodzieja, średniowiecznego mistrza lub alchemika, który ożywia materię w domowym laboratorium. Niektórzy publicyści nadal tytułowali go profesorem, choć edukację skończył na gimnazjum.

Starewicz to wielki miłośnik przyrody. Profesor geografii, botaniki i zoologii, uparty kolekcjoner owadów i różnych zwierzaków. W życiu natury dopatrzył się niezwykłych tajemnic, zrozumiał mowę kwiatów i zwierząt. To tajemnicze życie postanowił uchwycić na taśmę filmową [...][25]

- pisał dziennikarz po wizycie w Fontenay. $\mathrm{Z}$ biografią Starewicza nierozerwalnie łączą się jego artystyczne kreacje odgrywane poza planem. Nie chciał być biznesmenem, lecz czarodziejem.

Radykalne poglądy i przymus grania roli w teatrze życia utrudniają niestety robienie interesów. „Czarodziej z Fontenay” przekonał się o tym wiele razy. Marcin Giżycki, opierając się na wypowiedzi prasowej, sugeruje na przykład, że „przed zamieszkaniem w Polsce powstrzymywał [...] Starewicza jego antysemityzm" [26]. To chyba zbyt mocna teza, ale nie ulega wątpliwości, że antypatie reżysera przeszkadzały w rozpowszechnianiu jego fil-

[23] T. Żeromski, W gościnie u czarodzieja, „Ilustrowana Republika” 1929, nr 136.

[24] Y. Tsivian, The Case of the Bioscope Beetle:

Starewicz's Answer to Genetics, „Discourse” 1995, vol. 17 , no. 3 .

[25] Z.K.J., W willi wielkiego czarodzieja, „Głos Pracownika Polskiego" 1938, nr 4, s. 15.

[26] M. Giżycki, Przed 1945: Prekursorzy i pionie$r z y$, w: Polski film animowany, pod red. M. Giżyckiego i B. Zmudzińskiego, PWA, Warszawa 2008, s. 13, przyp. 10. Forda cytuje W. Jewsiewicki (op. cit., s. 181). 
mów. W wywiadzie udzielonym Charlesowi Fordowi Starewicz mówił, że w ojczystym kraju byłby gotów oddać swoje filmy za darmo, byle wzięła je firma „prawdziwie polska, narodowa”. Firmie niepolskiej, a więc - jak łatwo się domyślić - o kapitale żydowskim, nie chciał sprzedać kopii nawet za „największe pieniądze”. Prawdopodobnie $\mathrm{z}$ tak błahego powodu Reineke Fuchs ani inne znakomite filmy nie trafiły na rodzime ekrany. Disney podobno też był antysemitą, ale umiał oddzielić biznes od poglądów.

Z wywiadów, reportaży i wspomnień wyłania się nie tylko człowiek o trudnym charakterze, inteligentny i sarkastyczny, ale również ktoś, kto łączył przeciwstawne cechy charakteru lub biegunowo różne przekonania: antysemityzm i staropolską gościnność, nienawiść do popkultury i głód uznania w oczach masowej widowni. Konsekwentnie deklarował się jako artysta z powołaniem, gardził komercją i Hollywood, nie był również fanem kina dźwiękowego, które nazwał „tanim efektem pozbawionym estetycznych wartości, niegodnym miana sztuki"[27]. Z drugiej strony, obcy mu był radykalizm awangardy. Tworzył kino narracyjne, nawet nieco staroświeckie w formie; lubił ponadto odwoływać się do tradycji baśniowej i ezopowej. Pod względem artystycznym jego filmy obejmują pełną skalę - od sentymentalnego kiczu po stylistyczne nowatorstwo.

[27] A. Janta-Połczyński, U Władysława Starewicza, „Ilustrowany Kurier Codzienny” 1930, 8 stycznia (nr 7).

[28] W. Starewicz, Pamiętniki (1946), „Film na Świecie" 1984, nr 307/308, s. 26. Pisownia oryginalna.

[29] Guide to Film-Going, „Cinema Quarterly” 1934, vol. 2, no. 3, s. 190.

[30] To nie przypadek. Ekipa oglądała filmy Starewicza, szukając w nich inspiracji. Zob. A. McMahan, The Films of Tim Burton. Animating Live Action in Contemporary Hollywood, Continuum, New York-London 2006, s. 94.
Jak na prawdziwego artystę przystało, interesował się samym procesem kreacji. Kręcenie filmu przyrównywał do układania bukietu. „Gdzie umieszczam bukiet? [...] Nie ja to robię i nie moja to sprawa. - Prawdopodobnie umieszczą tam gdzie najwięcej zapłacą"28 - pisał gorzko w Pamiętnikach. Moim zdaniem nie przejmował się również modnymi konwencjami ani tym, jak gotowe dzieło zostanie przyjęte. $\mathrm{W}$ jego lekceważącej postawie wobec praw rynku ktoś mógłby wyczuć donkiszoterię człowieka oderwanego od swych korzeni, który ucieka od brutalnej rzeczywistości do wyidealizowanego świata baśni, ale paradoks polega na tym, że Starewicz walczył o uznanie i lubił popularność, dzięki której mógł bardziej przekonująco grać rolę naukowca i czarodzieja. W niektórych okresach żył wyłącznie z kręcenia reklam, ale chciał zostać zapamiętany jako nietuzinkowy artysta.

W filmach Starewicza pojawiają się sceny i obrazy, które nawet dziś mogą wydawać się szokujące w kinie animowanym. Zwłaszcza realistycznie ukazana przemoc, zgodna $\mathrm{z}$ surowymi regułami sztuki ludowej, kłóci się z konwencjami rozrywki dla najmłodszych. Dziennikarz „Cinema Quarterly”, pisząc krytycznie o filmie The Mascot (oryg. Fetiche-mascotte, 1933), zauważył, że ten w zamierzeniu „dziecięcy sen” graniczy z koszmarem przez swą „makabryczną atmosferę i groteskową fantazje”, a fabułę nazwał „miejscami niejasną" [29]. W filmie oglądamy m.in. sabat potworów pod przewodnictwem diabła i scenę pijackiej libacji, jedna $\mathrm{z}$ bohaterek kreowana jest na prostytutkę, za scenerię służy miasto pogrążone w demoralizacji i biedzie Wielkiego Kryzysu. Dziś surrealistyczny, oparty na luźnej konstrukcji fabularnej Fetysz uchodzi za prekursora takich filmów, jak Miasteczko Halloween (Nightmare before Christmas, 1994) Henry'ego Selicka i Tima Burtona[30]. W latach 30. połączenie konwencji horroru, czarnej komedii, tradycji ezopowej i filmu społecznie zaangażowanego mogło uchodzić za zbyt ekstrawaganckie. 


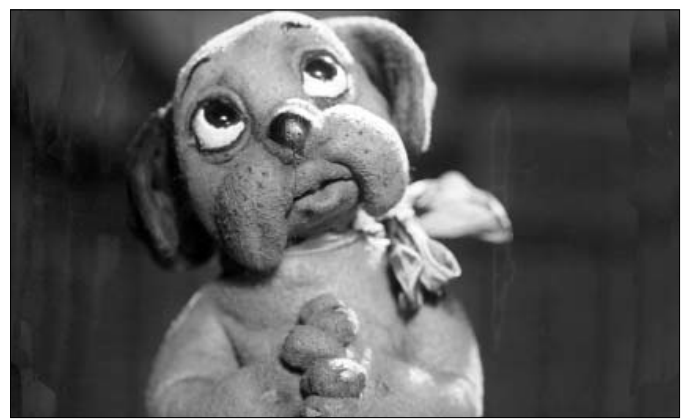

Fetysz maskotka Władysława Starewicza. Surrealistyczny film dla dzieci o problemach dorosłego świata

Przed śmiercią Starewicz popadł w całkowite zapomnienie. W latach 6o. styl jego animacji musiał wydawać się anachroniczny. Nowe tendencje w kinie lalkowym polegały na odejściu od realizmu w stronę umowności i symbolu. $\mathrm{Z}$ pisanych po wojnie Pamiętników wynika, że mimo wszystko wierzył $\mathrm{w}$ to, że dokonał w swoim życiu ważnych osiągnięć - jako pionier „ożywionej plastyki” i bezkompromisowy autor filmu lalkowego. Renesans jego twórczości przypada dopiero na lata 8o. XX wieku.

Wielu równie utalentowanych animatorów porzuciło przed wojną tę wymagającą profesję, gdyż nie mogli poradzić sobie z dużo mniejszymi przeciwnościami. Starewicza nie zniechęciły ani dwie wojny światowe, rewolucja i tułaczka po Europie, ani przełom dźwiękowy, po którym nastąpił bolesny kryzys ekonomiczny, ani nawet brak zainteresowania ze strony dystrybutorów i problemy finansowe. Do dziś jednak nie zdobył mistrz Starewicz rozgłosu, na jaki zasługuje jako autor filmów nie tylko zabawnych i znakomicie zrealizowanych, ale również głębokich, przesiąkniętych duchem humanizmu, odwołujących się do najlepszych tradycji sztuki europejskiej i ludowej. Wizerunek „tresera owadów” to zdecydowanie za mało.

\title{
Metodologia nowej historii filmu
}

\author{
MAREK HENDRYKOWSKI
}

Uniwersytet im. Adama Mickiewicza

\section{Wokół definicji}

Pierwsza polska definicja pojęcia filmowej nouvelle histoire została zaprezentowana w Słowniku terminów filmowych ponad dwadzieścia lat temu i brzmiała następująco:

światowy nurt refleksji historycznofilmowej dekady lat osiemdziesiątych skoncentrowany na rewizji tradycyjnej metodologii historii filmu, poszukiwaniu efektywniejszych procedur badawczych oraz na źródłowych badaniach dziejów kinematografii i sztuki filmowej prowadzących do ich nowego odczytania i reinterpretacji dotychczasowego obrazu historii filmu[1].

Nouvelle histoire (określenia synonimiczne: New Film History, nowa historia filmu etc.) w swojej międzynarodowej reprezentacji i wieloistnym zróżnicowaniu była wówczas kojarzona z nazwiskami takich badaczy historii kina, jak: Robert C. Allen, Douglas Gomery, Richard Abel, Michèle Lagny (wieloletnia redaktorka znakomitego paryskiego periodyku filmowego „Iris”), Noël Burch, Thomas Elsaesser, André Gaudreault, Tom Gunning, Charles Musser, Paolo Cherchi Usai, Michaił Jampolski, Jurij Cywjan (Yuri Tsivian), Richard Koszarski (zasłużony założyciel i lider amerykańskiego czasopisma „Film History”), Ben Brewster, Kevin Brownlow, a w Polsce - Alina Madej i Małgorzata Hendrykowska.

Charakterystyczną właściwością przytoczonej definicji nouvelle histoire jest jej, by tak rzec, programowo rewizyjny charakter. Nowa histo-

[1] M. Hendrykowski, Słownik terminów filmowych, hasło: nouvelle histoire, Ars Nova, Poznań 1994, s. 196. 